\title{
THE ROLE OF EXTRACELLULAR CALCIUM AND OTHER IONS IN THE SECRETORY RESPONSES OF THE EXOCRINE PANCREAS TO CHOLECYSTOKININ
}

\author{
TOMIO KANNO, IZUMI SHIBUYA ${ }^{1}$ and NAOTO ASADA ${ }^{2}$
}

Department of Physiology, Faculty of Veterinary Medicine, Hokkaido University, Sapporo 060, Japan

\begin{abstract}
The influence of extracellular $\mathrm{Ca}^{2+}$ and other ions was examined in the isolated perfused rat pancreas. Continuous stimulation with cholecystokinin (CCK) at a physiological concentration $\left(2 \times 10^{-11} \mathrm{M}\right)$ induced gradual increase in pancreatic protein output and juice flow. These CCK-induced secretory responses were completely abolished when $\mathrm{Ca}^{2+}$ was removed from the perfusing and bathing solution, and the responses reappeared when $2.5 \mathrm{mM} \mathrm{CaCl} \mathrm{mas}_{2}$ reintroduced. Continuous stimulation with CCK at a higher concentration $\left(3 \times 10^{-10} \mathrm{M}\right)$ induced secretory responses which consisted of two phases, an initial rising phase and a subsequent plateau. When $\mathrm{Ca}^{2+}$ was removed from the extracellular environment, the initial phase was decreased and the second phase was strongly inhibited. When all $\mathrm{Cl}^{-}$ in the perfusing solution was replaced by $\mathrm{SO}_{4}{ }^{2-}$, the secretory responses to $\mathrm{CCK}$ at physiological and higher concentrations were strongly inhibited. When $\mathrm{Cl}^{-}$was replaced with $\mathrm{Br}^{-}$, the secretory responses to $\mathrm{CCK}$ were slightly inhibited. Addition of $4.9 \mathrm{mM}$ Na-pyruvate, $2.7 \mathrm{mM} \mathrm{Na}$-fumarate, and $4.9 \mathrm{mM}$ Na-glutamate to the perfusing solution induced inhibition of the CCK-induced secretory responses.
\end{abstract}

Secretion has been defined as a chain of processes in which the following three main steps may be observed: ingestion, synthesis, and extrusion (4). Although ingestion and synthesis are a relatively continuous process in the pancreatic acinar cell, extrusion of zymogen granules by exocytosis occurs episodically in response to food ingestion. Extrusion is physiologically controlled by the gut hormone cholecystokinin-pancreozymin (CCK) and the neurotransmitter acetylcholine (ACh). It is commonly believed that the extrusion effect of these secretagogues is exerted by increasing the cytoplasmic concentration of free, diffusible $\mathrm{Ca}^{2+},\left[\mathrm{Ca}^{2+}\right]_{i}$. In fact, a recent study

Present address: ${ }^{1}$ Deparment of Physiology Yamagata University, School of Medicine, Yamagata 990-23; ${ }^{2}$ Division of Nutrition Physiology, Hokkaido Educational College, Hokumoncho, Asahikawa 070, Japan showed that $\left[\mathrm{Ca}^{2+}\right]_{i}$ is most effective in the comparatively narrow range between 0.4 and $1 \mu \mathrm{M}$ (15).

Two views have been proposed on the nature of the process responsible for the secretagogueinduced rise in $\left[\mathrm{Ca}^{2+}\right]_{i}$. The first view is that the rise may be produced by an increase in $\mathrm{Ca}^{2+}$ entry into the pancreatic acinar cell, and the second view is that the rise may be due to a release of $\mathrm{Ca}^{2+}$ from intracellular stores $(1,22)$. A compromise view in recent years is that the initial secretagogue action is to release intracellular $\mathrm{Ca}^{2+}$ followed by the sustaining phase of extrusion which may be due to a sustaining influx of extracellular $\mathrm{Ca}^{2+}(16,22)$. Previous studies in our laboratory provided evidence that the amylase output induced by $5 \mathrm{mU} / \mathrm{ml}(3.7 \times$ $\left.10^{-10} \mathrm{M}\right) \mathrm{CCK}$ was inhibited by the addition of $\mathrm{Mn}^{2+}$, an inhibitor of the $\mathrm{Ca}^{2+}$ influx (7), and that the amylase output induced by $\mathrm{ACh}$ at a low 
concentration $\left(5 \times 10^{-8} \mathrm{M}\right)$ was strongly reduced in a $\mathrm{Ca}^{2+}$-deficient environment, whereas the output induced by $\mathrm{ACh}$ at a high concentration $\left(10^{-6} \mathrm{M}\right)$ was not inhibited but rather enhanced by the $\mathrm{Ca}^{2+}$ removal (6). Although ACh is the chemical transmitter of the vagus nerve innervating the pancreas, the exact range of $\mathrm{ACh}$ concentration in physiological conditions is hard to determine. On the other hand, the physiological range of CCK level in the plasma can be determined, and the present experiments showed, for the first time, that the secretory responses induced by $\mathrm{CCK}$ at a physiological concentration $(2 \times$ $10^{-11} \mathrm{M}$ ) were completely inhibited in a $\mathrm{Ca}^{2+}$ deficient environment.

\section{MATERIALS AND METHODS}

\section{Isolation and Perfiusion of the Pancreas}

Sprague-Dawley strain rats (about $200 \mathrm{~g}$ ) were fasted but allowed water for $24 \mathrm{~h}$ before each experiment. The isolated and perfused pancreas was prepared as reported previously (11). Briefly, under ether anesthesia, the vascular system was cannulated and perfused through the superior mesentric and coeliac arteries, with the portal vein as outlet. The rate of vascular flow was kept constant at $2 \mathrm{ml} / \mathrm{min}$ by a roller pump. The hepatic end of the duct was ligated and the pancreatic juice was collected from the duodenal end following cannulation with a stainless steel tube. The blood supplying the stomach, liver, and spleen was stopped by tying the arteries. The mesentry with its embedded whole pancreas and the attached duodenum was isolated, and then placed in a Lucite chamber containing $20 \mathrm{ml}$ of a HEPES-buffered Ringer solution, maintained at $37^{\circ} \mathrm{C}$.

\section{Solution and Drugs}

The composition of the standard HEPESbuffered Ringer solution used for perfusing and bathing the preparation was as follows ( $\mathrm{mM})$ : $\mathrm{NaCl}, 145 ; \mathrm{KCl}, 5.6 ; \mathrm{CaCl}_{2}, 2.5 ; \mathrm{MgCl}_{2}, 1$; HEPES ( $N$-2-Hydroxyethyl piperazine- $N$ '-2ethane sulfonic acid: Sigma, St. Louis), 10; glucose, 5. In the $\mathrm{Ca}^{2+}$-deficient solution, $\mathrm{CaCl}_{2}$ was omitted. Dextran T-70 (Pharmacia, Uppsala) was added to the perfusing solution at a final concentration of $5 \%(\mathrm{w} / \mathrm{v})$. The solution was equilibrated with $\mathrm{O}_{2}$ and had a pH of 7.3. CCK (33 amino acid residues; $3,500 \mathrm{U} / \mathrm{mg}$, by the courtesy of Professor Mutt, Karolinska Institute, Stockholm) was added to the perfusing solution. CCK was stored frozen at a concentration of $30 \mu \mathrm{M}$ in a stock physiological saline solution containing $0.5 \%$ bovine serum albumin (ICN Nutritional Biochemicals, Cleveland, U.S.A.) and $0.05 \%$ ammonium bicarbonate (Wako Pure Chemical Ind., Tokyo). This procedure assures the effectiveness of CCK (2).

\section{Estimation of Digestive Enzyme}

The collected juice sample was then diluted with $160 \mathrm{mM} \mathrm{NaCl}$ solution containing phosphate buffer $(\mathrm{pH}$ 7.1). The total protein in the pancreatic juice was assayed by the method of Lowry et al. (12), with bovine serum albumin as a standard.

\section{Statistics}

Results are expressed as the mean $\pm \mathrm{SE}$ of several experiments, and are analyzed by Student's $t$-test.

\section{RESULTS}

\section{Influence of $\mathrm{Ca}^{2+}$ Removal on Secretory Responses Induced by CCK at Different Concentrations}

Continuous stimulation with CCK at a low concentration $\left(2 \times 10^{-11} \mathrm{M}\right)$ induced gradual increases in pancreatic protein output and juice flow (Fig. 1). The total protein output in the 30 min of continuous stimulation in the standard solution was $3,147 \pm 199 \mu \mathrm{g}$. The secretory responses were completely inhibited when $\mathrm{Ca}^{2+}$ was removed from the perfusing and bathing solution (Fig. 2). The total amount of CCKinduced protein output into the common duct collected in the $\mathrm{Ca}^{2+}$-deficient environments was $198 \pm 70 \mu \mathrm{g}$ per $30 \mathrm{~min}$. Analysis of these two results showed that the diminution of CCKinduced protein output was significant $(P<$ 0.001). The strong inhibition of secretory responses to continuous $\mathrm{CCK}$ stimulation in the $\mathrm{Ca}^{2+}$-deficient environment was followed by detectable rises in pancreatic protein output and juice flow when $2.5 \mathrm{mM} \mathrm{CaCl}_{2}$ was reintroduced to the perfusing and bathing solution in the absence of CCK (Fig. 2).

Continuous stimulation with CCK at a moderate concentration $\left(5 \times 10^{-11} \mathrm{M}\right)$ induced secretory responses which consisted of two phases, an initial rising and a decline (Fig. 1). The total protein output in the $30 \mathrm{~min}$ of continuous stimulation in the standard solution was $5,707 \pm$ $252 \mu \mathrm{g}$. When $\mathrm{Ca}^{2+}$ was removed from the per- 

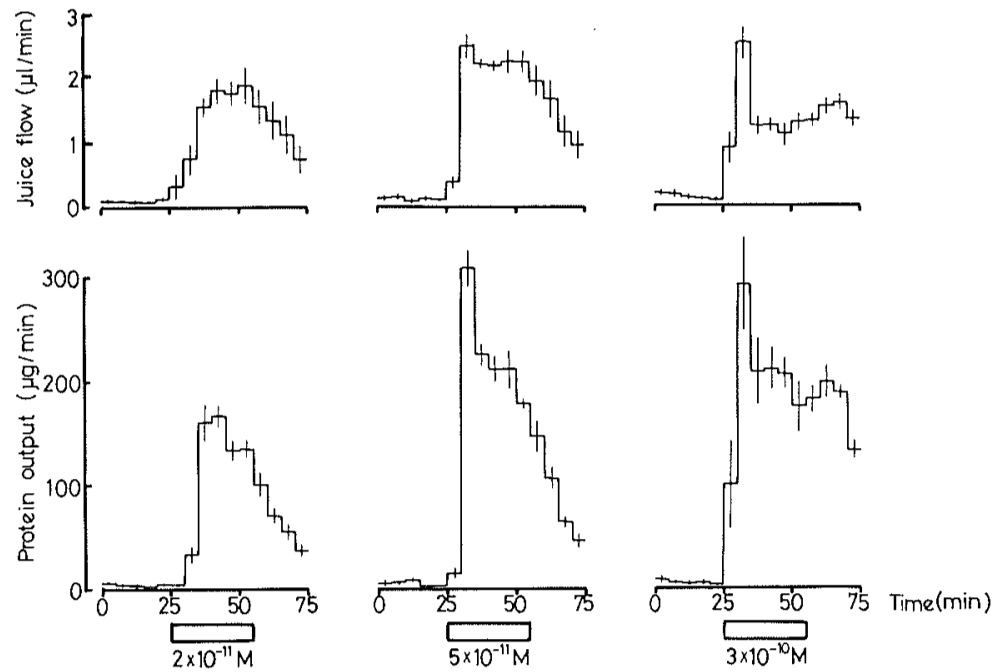

Fig. 1 Time course of changes in pancreatic juice flow and protein output during continuous perfusion of the isolated rat pancreas with $2 \times 10^{-11} \mathrm{M}(0.27$ $\mathrm{mU} / \mathrm{ml}), 5 \times 10^{-11} \mathrm{M}$, and $3 \times 10^{-10} \mathrm{M} \mathrm{CCK}$ in the standard solution. Each value represents the mean of four experiments. The open horizontal bar indicates the period of CCK perfusion.
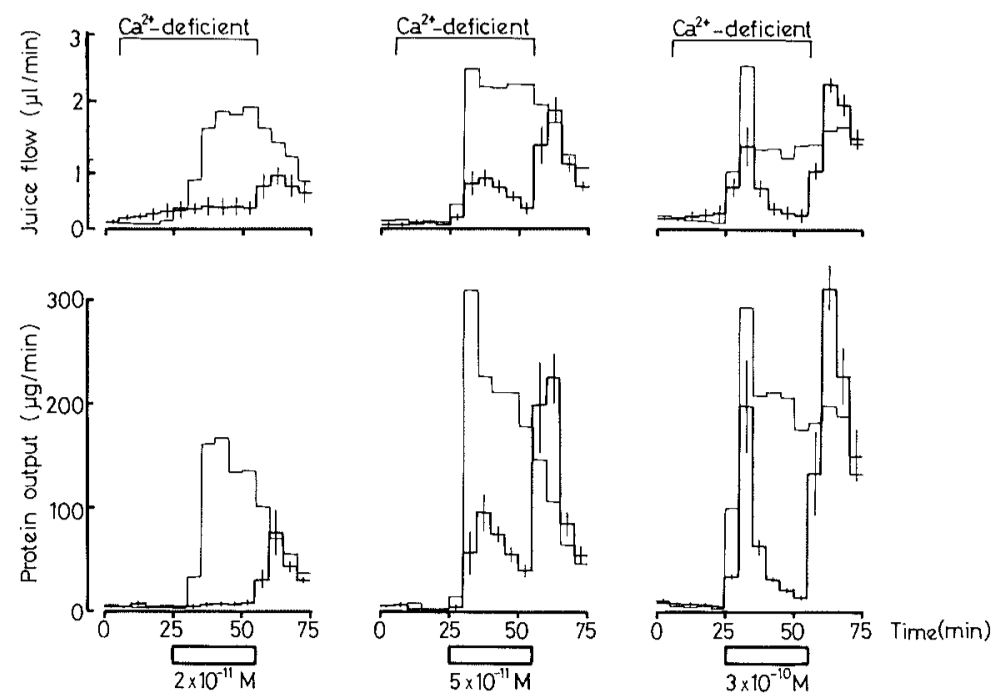

Fig. 2 Time course of changes in pancreatic juice flow and protein output during continuous perfusion of the isolated rat pancreas with $2 \times 10^{-11} \mathrm{M}$, $5 \times 10^{-11} \mathrm{M}$, and $3 \times 10^{-10} \mathrm{M} \mathrm{CCK}$ in a $\mathrm{Ca}^{2+}$-deficient solution $\left(\mathrm{CaCl}_{2}\right.$ was removed from the perfusing and the bathing solution). Responses induced by $\mathrm{CCK}$ in the standard solution containing $2.5 \mathrm{mM} \mathrm{CaCl}_{2}$ (Fig. 1) are indicated by thin lines for reference. Each value represents the mean of four experiments. The open horizontal bar indicates the period of CCK perfusion. 
fusing and bathing solution, the initial and second phases were both decreased to about one third of the respective controls obtained in the standard solution. The total amount of $\mathrm{CCK}$ induced protein output into the common duct collected in the Camdeficient environment was $1,650 \pm 317 \mu \mathrm{g}$ per $30 \mathrm{~min}$. Analysis of these two results showed that the diminution of $\mathrm{CCK}$ induced protein output was significant $(P<$ $0.001)$. The strong inhibition of secretory responses to continuous CCK stimulation was followed by marked increases in pancreatic protein output and juice flow when $2.5 \mathrm{mM} \mathrm{CaCl}$ was reintroduced to the perfusing and bathing solution in the absence of CCK (Fig. 2).

Continuous stimulation with $\mathrm{CCK}$ at a higher concentration $\left(3 \times 10^{-10} \mathrm{M}\right)$ induced secretory responses which consisted of two phases, an initial rising phase and a subsequent plateau (Fig. 1). The total protein output in the $30 \mathrm{~min}$ of continuous stimulation in the standard solution was $5,923 \pm 618 \mu \mathrm{g}$. When $\mathrm{Ca}^{2+}$ was removed from the perfusing and bathing solution, the initial phase was decreased to about twothirds of the control obtained in the standard solution, and the second phase was strongly inhibited. The total amount of CCK-induced protein output into the common duct collected in the $\mathrm{Ca}^{2+}$-deficient environment was $1,832 \pm 245$ $\mu \mathrm{g}$ per $30 \mathrm{~min}$. Analysis of these two results showed that the diminution of CCK-induced protein output was significant $(P<0.001)$. The strong inhibition of secretory responses to continuous CCK stimulation was followed by marked rises in pancreatic protein output and juice flow when $2.5 \mathrm{mM} \mathrm{CaCl} \mathrm{mas}_{2}$ waintroduced to the perfusing and bathing solution in the absence of CCK (Fig. 2).

\section{Influence of $\mathrm{Cl}^{-}$Replacement on Secretory Responses Induced by CCK at Different Concentrations}

When all $\mathrm{Cl}^{-}$in the perfusing solution was replaced by $\mathrm{SO}_{4}{ }^{2-}$, not only the secretory responses to continuous CCK stimulation but also the responses to $\mathrm{CaCl}_{2}$ reintroduction were strongly inhibited (Fig. 3). The inhibitory influence of $\mathrm{SO}_{4}{ }^{2-}$ may be attributable to decrease in the $\left[\mathrm{Ca}^{2+}\right]_{0}$, although we used $10 \mathrm{mM} \mathrm{CaSO}_{4}$ to compensate for the low $\mathrm{Ca}^{2+}$ ion concentration that exists in the presence of sulphate. When all $\mathrm{Cl}^{-}$was replaced by $\mathrm{Br}^{-}$, however, the secretory responses to $2 \times 10^{-11} \mathrm{M}$ or $5 \times 10^{-11} \mathrm{M}$ CCK were slightly and insignificantly inhibited, but the responses to $3 \times 10^{-10} \mathrm{M} \mathrm{CCK}$ were significantly inhibited ( $P<0.02$; Fig. 4).
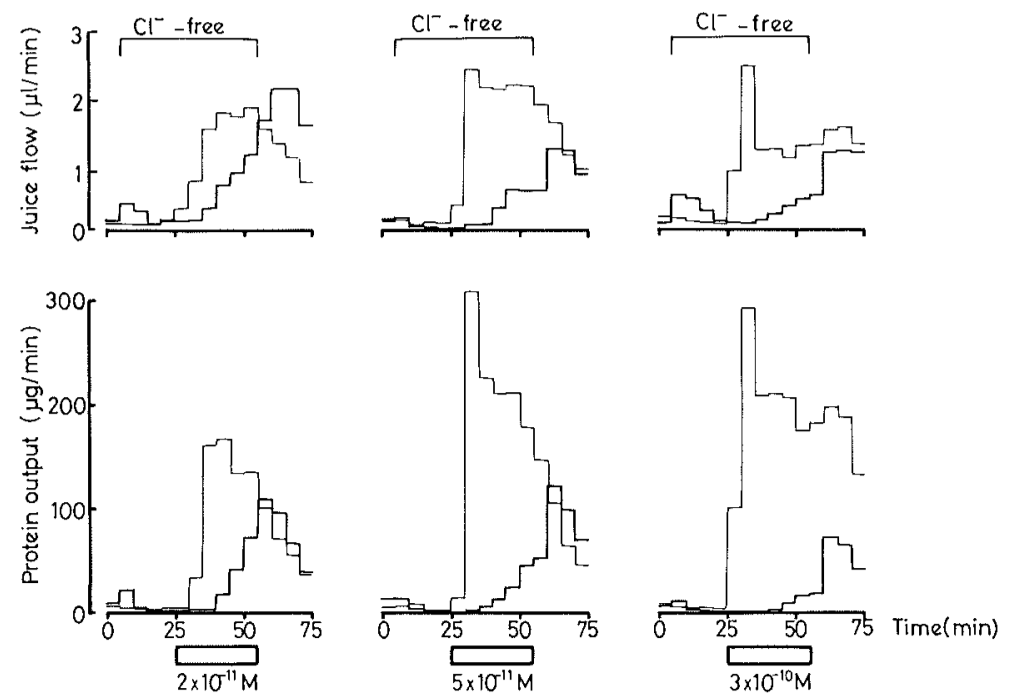

Fig. 3 Time course of changes in pancreatic juice flow and protein output during continuous perfusion of the isolated rat pancreas with $2 \times 10^{-11} \mathrm{M}$, $5 \times 10^{-1} 1 \mathrm{M}$, and $3 \times 10^{-10} \mathrm{M} \mathrm{CCK}$ in a $\mathrm{Cl}^{-}$-free solution $\left(\mathrm{Cl}^{-}\right.$was replaced with $\mathrm{SO}_{4}{ }^{2-}$ ). Responses induced by $\mathrm{CCK}$ in the standard solution (Fig. 1) are indicated by thin lines for reference. Each value represents the mean of two experiments. The open horizontal bar indicates the period of $\mathrm{CCK}$ perfusion. 

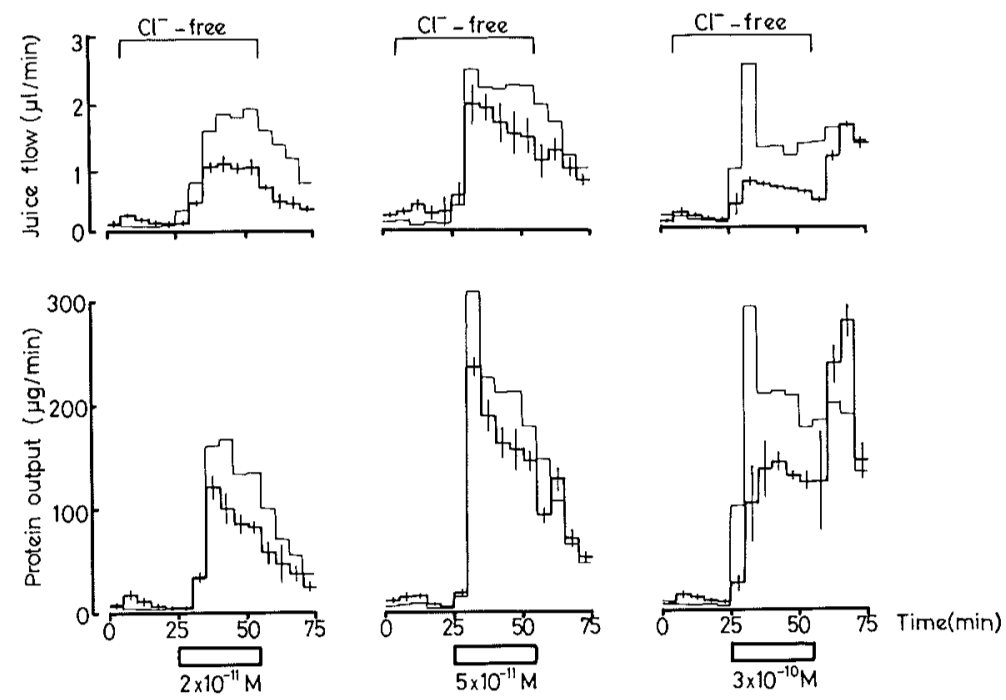

Fig. 4 Time course of changes in pancreatic juice flow and protein output during continuous perfusion of the isolated rat pancreas with $2 \times 10^{-11} \mathrm{M}$, $5 \times 10^{-11} \mathrm{M}$, and $3 \times 10^{-10} \mathrm{M} \mathrm{CCK}$ in a $\mathrm{Cl}^{-}$-free solution $\left(\mathrm{Cl}^{-}\right.$was replaced with $\mathrm{Br}^{-}$). Responses induced by $\mathrm{CCK}$ in the standard solution (Fig. 1) are indicated by thin lines for reference. Each value represents the mean of four experiments. The open horizontal bar indicates the period of CCK perfusion.
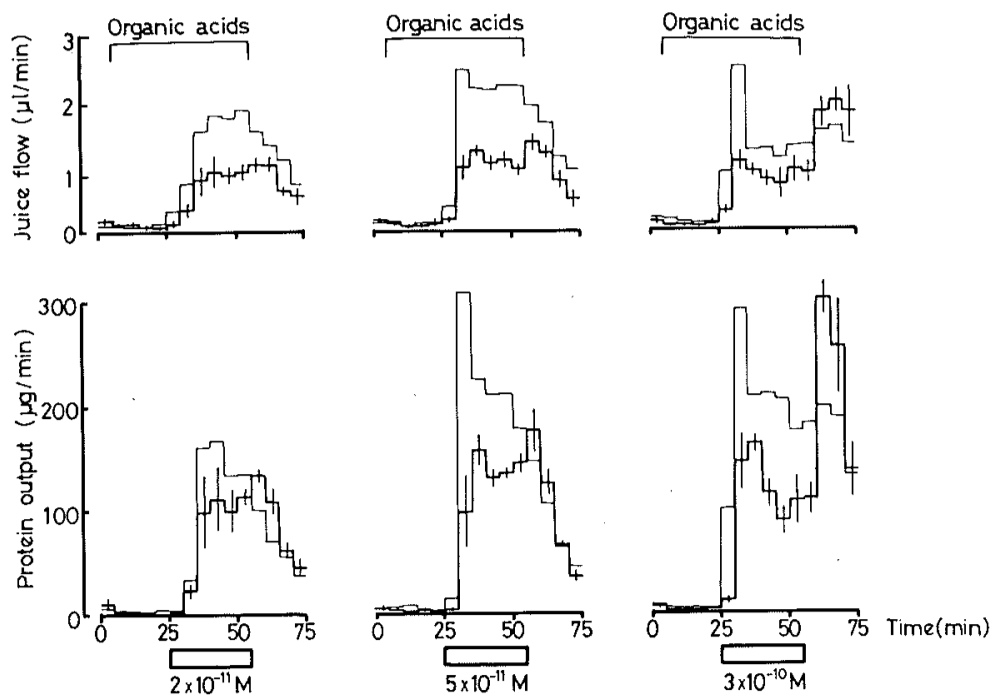

Fig. 5 Time course of changes in pancreatic juice flow and protein output during continuous perfusion of the isolated rat pancreas with $2 \times 10^{-11} \mathrm{M}$, $5 \times 10^{-11} \mathrm{M}$, and $3 \times 10^{-10} \mathrm{M}$ CCK in a solution containing organic acids $(4.9$ $\mathrm{mM}$ Na-pyruvate, $2.7 \mathrm{mM}$ Na-fumarate, and $4.9 \mathrm{mM}$ Na-glutamate). Responses induced by CCK in the standard solution (Fig. 1) are indicated by thin lines for reference. Each value represents the mean of four experiments. The open horizontal bar indicates the period of CCK perfusion. 


\section{Influence of Organic Acids on Secretory Responses Induced by CCK at Different Concentrations}

The solution superfusing or bathing the pancreas fragments, dispersed acini or acinar cells frequently contains organic acids. For example, solution containing $4.9 \mathrm{mM}$ Na-pyruvate, 2.7 $\mathrm{mM}$ Na-fumarate, and $4.9 \mathrm{mM}$ Na-glutamate has been used to superfuse the pancreatic fragments $(13,14,16)$. The influence of the addition of these organic acids to the perfusing and bathing solution on the secretory responses to CCK was examined in the isolated perfused rat pancreas (Fig. 5). When $4.9 \mathrm{mM}$ Na-pyruvate, $2.7 \mathrm{mM} \mathrm{Na-fumarate,} \mathrm{and} 4.9 \mathrm{mM} \mathrm{Na}$-glutamate were added to the standard solution, the protein output induced by continuous stimulation with $2 \times 10^{-11} \mathrm{M}$ CCK was slightly inhibited. The difference between the total amount of CCKinduced protein output in the presence of the organic acids and that in the absence of the organic acids was not significant $(P>0.1)$. The pancreatic juice flow induced by $2 \times 10^{-11} \mathrm{M}$ CCK in the presence of the organic acids was significantly smaller than in the absence of organic acids $(P<0.02)$. The protein output and the juice flow induced by $5 \times 10^{-11} \mathrm{M}$ or $3 \times 10^{-10} \mathrm{M}$ CCK in the presence of the organic acids were significantly smaller than the corresponding values obtained in the absence of organic acids $(P<0.01)$.

\section{DISCUSSION}

\section{Physiological, Pharmacological, and Pathological Effects of CCK}

Grossman (3) has proposed the following criteria for the physiological effect of gastroenteric hormones: 1) the effect should be seen with doses of exogenous hormone equivalent to the $\mathrm{ED}_{50}$ (dose inducing half-maximum responses) for primary action; 2) application by continuous intravenous infusion, not by bolus; and 3) the action should be seen with endogenous release of the hormone. We have no information about the range of plasma CCK level before and after eating in the rat, but it has been estimated by bioassay that the vascular perfusate of the isolated perfused rat duodenum contained about $7 \mathrm{mU} / \mathrm{ml}\left(5.1 \times 10^{-10} \mathrm{M}\right) \mathrm{CCK}$ after intraduodenal infusion of a synthetic trypsin inhibitor, FOY $305(100 \mathrm{mg} / \mathrm{kg}$ body weight), which is known to be a most effective stimulus for endogenous CCK release (10), CCK in the portal vein is known to be partly inactivated in the plasma and during the pass through the liver, and further diluted about three times with venous blood passed through organs other than the liver. It seems reasonable that the rise in CCK level in response to food ingestion should be far below the level of $5 \times 10^{-10} \mathrm{M}$ in the arterial blood perfusing the pancreas in situ, and the secretory response to $2 \times 10^{-11} \mathrm{M}$ CCK is regarded as a physiological effect. $\mathrm{CCK}$ in the range from $5 \times 10^{-10} \mathrm{M}$ to $2 \times 10^{-9} \mathrm{M}$ may induce pharmacological effects. CCK in the range above $2 \times 10^{-9} \mathrm{M}$ may cause pathological effects: the effects were much smaller than the physiological and pharmacological effects (5), and coincided with uncoupling between adjacent acinar cells, leading to leakage of pancreatic enzyme and zymogen from the acinar lumen to the portal vein (20).

\section{$\left[\mathrm{Ca}^{2+}\right]_{0}$ on the Secretory Responses}

The present experiments provide direct evidence that $\mathrm{CCK}$ requires extracellular $\mathrm{Ca}^{2+}$ in order to induce secretory effects in the isolated perfused rat pancreas. The requirement of extracellular $\mathrm{Ca}^{2+}$ was most evident when the pancreas was continuously stimulated with $2 \times 10^{-11} \mathrm{M}$ CCK, a possible physiological concentration. The requirement of extracellular $\mathrm{Ca}^{2+}$ became gradually less as the CCK concentration used was increased: the initial phase of secretory responses to $3 \times 10^{-10} \mathrm{M}$ CCK remained but the plateau phase was almost completely abolished in a $\mathrm{Ca}^{2+}$-deficient environment (Fig. 2). These results lead us to conclude that 1) influx of extracellular $\mathrm{Ca}^{2+}$ is the dominant source of increase in $\left[\mathrm{Ca}^{2+}\right]_{i}$ when the pancreatic acinar cell is stimulated with CCK at a physiological concentration, and that 2) in addition to $\mathrm{Ca}^{2+}$ influx, $\mathrm{Ca}^{2+}$ is released from intracellular $\mathrm{Ca}^{2+}$ stores immediately after the cell is stimulated with CCK at a pharmacological concentration or at the upper limit of physiological concentration while the influx of extracellular $\mathrm{Ca}^{2+}$ is continuously increased. The present conclusion is consistent with the previous conclusion obtained from the study on the $\mathrm{Ca}^{2+}$-dependent secretory responses to ACh (6). The second conclusion corresponds to the view that the initial secretagogue action is to release intracellular $\mathrm{Ca}^{2+}$, that the resulting increase in $\left[\mathrm{Ca}^{2+}\right]_{\mathrm{i}}$ triggers exocytosis of zymogen granules, and that, in the sustaining phase of secretory response, influx of extracellular $\mathrm{Ca}^{2+}$ is important as the source of $\left[\mathrm{Ca}^{2+}\right]_{i}(16,22)$.

The pathological responses of the pancreatic acinar cell to CCK at a high concentration may be due to an extreme rise in $\left[\mathrm{Ca}^{2+}\right]_{\mathrm{i}}$, which may 
inhibit secretagogue-induced secretory responses (15), and cause uncoupling between adjacent cells (20).

In the context of the present study, it is interesting that the depolarizing effect of secretagogues has been demonstrated at pharmacological and pathological concentrations $(13,17)$, and the hyperpolarizing effect has been recorded at a physiological concentration $(5,8)$.

\section{$\left[\mathrm{Cl}^{-}\right]_{0}$ and Organic Acids on the Secretory Responses}

The ionic mechanism of the depolarizing effect of $\mathrm{ACh}$ has been studied by replacing the extracellular ions. The $\mathrm{Cl}^{-}$permeability was estimated by comparing the ACh-evoked depolarization in a $\mathrm{Cl}^{-}$-rich solution and that in a solution in which $\mathrm{Cl}^{-}$was replaced with $\mathrm{SO}_{4}{ }^{2-}$ (14). In the $\mathrm{Cl}^{-}$-free solution, the caerulein-evoked amylase and fluid secretion were strongly inhibited (18). Although Petersen and Ueda (18) used $10 \mathrm{mM} \mathrm{CaSO}_{4}$ to compensate for the low $\left[\mathrm{Ca}^{2+}\right]_{0}$ that exists in the presence of sulfate, this procedure may partially reduce the $\left[\mathrm{Ca}^{2+}\right]_{0}$, and may decrease the secretory responses of the pancreatic acinar cell to caerulein. A same explanation can be applied to the present results shown in Fig. 3. The previous study showed that the replacement of $\mathrm{NaCl}$ with $\mathrm{NaBr}$ has slight and insignificant influence on the CCKinduced secretory responses, whereas the replacement with $\mathrm{Na}$-isothionate or with $\mathrm{Na}$-pyruvate abolished the secretory responses (9). A similar result was obtained in the present experiments (Fig. 4). These results may be explained by the possibility that the hydrated isothionate and pyruvate ion do not readily cross the membrane whereas $\mathrm{Cl}^{-}$and $\mathrm{Br}^{-}$do. A similar explanation was given for the difference in the effects of isothionate, $\mathrm{Cl}^{-}$, and $\mathrm{Br}^{-}$on the post-tetanic hyperpolarization in mammalian non-myelinated nerve fibers (19). There is another possibility that the organic acids including amino acids and sugars per se may inhibit the secretagogueinduced secretory responses. The present study showed that the CCK-induced secretory responses were inhibited when $4.9 \mathrm{mM}$ Na-pyruvate, $2.7 \mathrm{mM}$ Na-fumarate, and $4.9 \mathrm{mM} \mathrm{Na-}$ glutamate were added to the perfusing solution (Fig. 5). A previous study in our laboratory provided evidence that an increase in sugar (glucose, xylose, and galactose) concentration in the perfusing solution inhibited the CCKinduced secretory responses (21). The depolarizing effect of secretagogues has usually been recorded from the pancreatic fragments superfused with a solution containing $4.9 \mathrm{mM} \mathrm{Na}$ pyruvate, $2.7 \mathrm{mM}$ Na-fumarate, and $4.9 \mathrm{mM}$ Na-glutamate $(13,14,17)$, and the secretory responses of the acinar cells in the fragment may, at least in part, be inhibited.

\section{Received for publication 25 April 1983}

\section{REFERENCES}

1. CAse R. M. (1978) Synthesis, intracellular transport and discharge of exportable proteins in the pancreatic acinar cell and other cells. Biol. Rev. 53, 211-354

2. Dimaline R. and Dockray G. J. (1979) Potent stimulation of the avian exocrine pancreas by porcine and chicken vasoactive intestinal peptide. J. Physiol. 294, 153-163

3. Grossman M.T. (1974) Gastrointestinal hormons: spectrum of actions and structuresactivity relations. In Endocrinology of the Gut (ed. Chey W. Y. and Brooks F. P.) Charles B. Slack, Thorofare, NJ, p. 65

4. Junqueira L. C. U. and Hirsch G. C. (1956) Cell secretion: a study of pancreas and salivary glands. Intern. Rev. Cytol. 5, 323-364

5. KanNo T. (1975) The electrogenic sodium pump in the hyperpolarizing and secretory effects of pancreozymin in the pancreatic acinar cell. $J$. Physiol. 245, 599-616

6. KanNo T. and Habara Y. (1980) The effect of acetylcholine concentration on membrane potential, redox state and secretion of the pancreatic acinar cell. Biomedical Res. 1, 66-75

7. Kanno T. and Nishimura O. (1976) Stimulussecretion coupling in pancreatic acinar cells: inhibitory effects of calcium removal and manganese addition on pancreozymin-induced amylase release. J. Physiol. 257, 309-324

8. Kanno T. and Saito A. (1976) The potentiating influences of insulin of pancreozymin-induced hyperpolarization and amylase release in the pancreatic acinar cell. J. Physiol. 261, 505-521

9. KanNo T, and Saito A. (1978) Influence of external potassium concentration on secretory responses to cholecystokinin-pancreozymin and ionophore A23187 in the pancreatic acinar cell. J. Physiol. 278, 251-263

10. Kanno T., Saito A., and Yonezawa H. (1980) Unidirectional cellular processes of stimulussecretion coupling in a cell secreting cholecystokinin-pancreozymin. In Histochemistry and Cell Biology of Autonomic Neurons, SIF Cells, and Paraneurons (ed. ERÄNKö O., SoINILA S. and PÄIVÄrinta H.) Raven Press, New York, pp. 327-332

11. Kanno T., Suga T. and Yamamoto M. (1976) Effects of oxygen supply on electrical and secretory responses of humorally stimulated acinar cells in isolated rat pancreas. Jap.J. Physiol. 26, 
101-115

12. Lowry O. H., Rosebrough N. J., Farr A. L. and Randall R. J. (1951) Protein measurement with the Folin phenol reagent. J. Biol. Chem. 193, 265-275

13. Matthews E. K., Petersen O. H. and WilLiams J. A. (1973) Pancreatic acinar cells: acetylcholine-induced membrane depolarization, calcium efflux and amylase release. J. Physiol. 234, 689-701

14. McCandless M., Nishiyama A., Petersen O. H. and Philpott H.G. (1981) Mouse pancreatic acinar cells: voltage-clamp study of acetylcholine-evoked membrane current. J. Physiol. 318, $57-71$

15. O'Doherty J. and STARK R. J. (1982) Stimulation of pancreatic acinar secretion: increases in cytosolic calcium and sodium. Amer. J. Physiol. 242, G513-G521

16. Petersen O. H., Maruyama Y., Graf J., Laugier R., Nishiyama A. and Pearson G. T. (1981) Ionic currents across pancreatic acinar cell membranes and their role in fluid secretion. Phil. Trans. Roy. Soc. London B 296, 151-166
17. Petersen O. H. and Matthews E. K. (1972) The effect of pancreozymin and acetylcholine on the membrane potential of the pancreatic acinar cells. Experientia 28, 1037-1038

18. Petersen O. H. and Ueda N. (1977) Secretion of fluid and amylase in the perfused rat pancreas. J. Physiol. 264, 819-835

19. RanG H. P. and Ritchie J. M. (1968) On the electrogenic sodium pump in mammalian nonmyelinated nerve fibres and its activation by various external cations. J. Physiol. 196, 183221

20. Saito A. and Kanno T. (1973) Concentration of pancreozymin as a determinant of the exocrineendocrine partition of pancreatic enzymes. Jap. J. Physiol. 23, 477-495

21. Saito A., Williams J. A. and Kanno T. (1980) Potentiation of cholecystokinin-induced exocrine secretion by both exogenous and endogenous insulin in isolated and perfused rat pancreata. $J$. Clin. Invest. 65, 777-782

22. Williams J. A. (1980) Regulation of pancreatic acinar cell function by intracellular calcium. Amer. J. Physiol. 238, G269-G279 